\title{
The Role of New Retailing Formats in the Italian Local Development
}

\author{
Antonio Mileti, M. Irene Prete, Gianluigi Guido \\ University of Salento, Lecce, Italy
}

\begin{abstract}
In Italy, and particularly in its southern area, super-markets and hyper-markets still represent an expanding retailing format, as they were introduced years later than in other western countries. Today, they have become large retailers capable of influencing local development from an economic, social and urban perspective. The literature concerned with their effects on the local economy has focused on labour markets, price dynamics, and inter-type competition, neglecting their impact on macroeconomic factors such as GDP, value added specific sectors-agriculture, industry and services. This study tries to contribute to fill this gap by empirically investigating associations between key characteristics of these retailers and specific macroeconomic value added factors.
\end{abstract}

Keywords: retailing, supermarkets, hypermarkets, value added, food sector, service sector, Italian development

\section{Introduction}

The retailing food sector has been the first one to experience the impact of modern retailing formats, as the main typologies of modern trade have found in their origin. Food sector dynamics still exert a strong influence on the micro- and macro- economic environment, agricultural and industrial production, transport, trade, consumption, as well as on some social and urban aspects (IRES, 2002; Lago, 2002; Prasad \& Reddy, 2007).

In Italy, the modernization of the retailing sector has driven a process of economic development and industrial restructuring, even though its delay in relation to other western countries and its heterogeneity over the national territory. On the other hand, the small retail trade has undertaken the role of social absorber and occupational stimulus, especially in the southern regions. The 1990s represented a turning point in the process of renovation of the retailing sector, as its inefficiencies were the recognised causes of the inflation process which produced detrimental effects on the purchasing power of salaries and on workers' retributive claims. Endogenous processes of rationalization and concentration and exogenous dynamics induced by the Italian legislator (Martora Law, Bersani Law, and the Reform of the Title V of the Italian Constitution) were activated. Since then, the trade sector has started a process similar to the one experienced by the manufacturing sector (Lago, 2002; Pellegrini, 2001), in

Antonio Mileti, Ph.D., Department of Business, Law and Environmental Studies, Faculty of Economics, University of Salento.

M. Irene Prete, Ph.D., MSc., research associate in Marketing, Department of Business, Law and Environmental Studies, Faculty of Economics, University of Salento.

Gianluigi Guido, full professor of Marketing, Department of Business, Law and Environmental Studies, Faculty of Economics, University of Salento.

Correspondence concerning this article should be addressed to M. Irene Prete, University of Salento, Ecotekne, Via per Monteroni, 73100 Lecce, Italy. E-mail: ireneprete@libero.it. 
particular: (1) the growth of big retailers, especially in southern Italy; (2) the concentration and the growing horizontal competition among retailing firms; (3) the entrance of new international retailing competitors and the success of new distribution techniques; and (4) the strong reduction of both small food and non-food retailers. This process has lead retailing companies to the control and standardization of quality, cost reductions through new operative and managerial techniques, personnel specialisation, and diffusion of more accurate information.

Because of these phenomena, super-markets and hyper-markets could be considered as a relatively new form of large retailing formats especially in southern Italy—still characterized by a persistent economic backwardness - where their introduction came with decades of delay with respect to other western countries, such as France, UK, Germany and the USA (Marbach, Barile, Carlucci, \& de Martino, 2000; Pellegrini, 2001). In Italy, super-markets and hyper-markets are defined according to their selling area: Supermarkets have a selling area between 400 and 2,500 square meters, while hypermarkets have a selling area greater than 2,500 square meters (Osservatorio Nazionale sul Commercio, 2004). Main characteristics of these retailing formats—-their bargaining strength, large dimension and ability to attract consumers-have allowed them to become large organisations potentially capable of influencing local development from an economic, social and urban perspective.

The aim of this paper is to investigate the impact of super-markets and hyper-markets on macro-economic factors, and, specifically, examining associations between key characteristics of the evolution of these retailers-their diffusion in the considered areas and their dimension-and specific macro-economic variables-GDP, total value added, value added in specific sectors, such as agriculture, industry and services. Results show that, in Italy, the presence of super-markets and hyper-markets differently interact with the abovementioned local development factors.

\section{The Retailing Sector and Local Economic Development}

Notwithstanding traditional forms of retailing represent an economic and urban phenomenon, they do not have, taken one by one, the ability to influence local equilibrium. On the contrary, modern retail companies have reached a dimension such that the choices concerned with their single creation need to be calibrated accurately, both by managers and local public administrators, because of their social, special and economic consequences on agriculture, industry and services. The establishment of relevant economic activities brings about effects of different nature, both for firms and the community, which can be classified in the following way: (1) general and sector-based economic effects on prices, income, employment and competitive equilibrium among firms and different retailing channels; (2) social effects concerned with mobility, aggregation, social, individual and cultural development; and (3) environmental effects on the territorial morphology, the ecosystems balances, and the degree of pollution in the areas characterized by new plants (Bertozzi, 2006; Guido, 2007).

Most of the prevailing literature has focused both on the study of the dynamics concerned with inter-format and intra-format power relationships, and on the exploration of economic, social and territorial factors that influence the large retailing localisation (Dunne \& Lusch, 1999). Only in the last years, some authors have highlighted that the retailers' power may represent a factor of disequilibrium for local economies.

The discussion on the way by which the impact of modern retailing, and, in particular, of super-markets and hyper-markets, can be evaluated, is intended to investigate economic and non-economic problems - which are often not directly quantifiable. Moreover, it is focused on analyzing the problems linked to the 
monopoly/monopsony power and, in general, all market failures (Beresteanu \& Ellickson, 2006; Clarke, 2001). More accurate studies have considered the effects induced by the creation of new selling points on prices and employment (Basker, 2005; Drewianka \& Johnson, 2006; Guariglia, 2002; Neumann, 2006). Furthermore, the evaluation of the consequences on local economies generated by new large retailers can be studied in a different theoretical framework, aimed to define methodological and operative implications and oriented to the interpretation of social, economic and territorial effects (IRES, 2002; Lago, 2002; Prasad \& Reddy, 2007).

\section{The Modernization of the Italian Retailing Sector: A Not Uniform Process}

The modernization of the Italian retailing sector has not been uniform, since it followed different dynamics as a consequence of sectorial, geographic and legislative concerns.

Owing to sectorial elements, the modernization process of the retailing sector has been sharper in the food sector than in the non-food one-even though the latter is experiencing an intense acceleration. The delay accumulated by the large non-food retailing companies seems to be dependent crucially on the nature of products, and, especially, on the high level of customer services required. The de-specialised food retailing stores have moved towards the increase of territorial coverage, as well as the enhancement of selling points areas. Their sector concentration has progressively raised and, according to the ACNielsen data, in 2006 the top ten companies reached $59.3 \%$ of the market share (the first six firms covered the $44.9 \%$ of the market share).

As a consequence of economic and competitive factors, the modernization process has involved primarily northern and central Italy. The widespread diffusion of large structures in these areas is due to different factors, specifically, similarity of their social-economic conditions with respect to other European countries (i.e., their high density population areas and urban concentration). Then, from the 1990s, the progressive reduction of geographic areas available for new plants in central/northern regions has pushed large structures towards southern Italy areas, where competitive dynamics were still weak.

Because of legislative aspects, geographical evolution and modernization of the Italian retail trade is affected by the specific licences and permits to operate a medium and large retail business. The Law 426/1971 shaped the retailing system and contributed to obstruct the modernization of the Italian retailing system, through: (1) the absence of both incentives to facilitate the growth of small and medium retail firms and of stimuli and pressures that, in other countries, have contributed to achieve high levels of efficiency; (2) the entrance of foreign competitors, and French ones in particular, which, after the saturation of their marketplace, have had the opportunity to strengthen themselves and grow into the Italian market leaders; (3) the absence of agreements able to foster synergies between international retail companies and to strengthen the supremacy and the control of the territory; and (4) the presence of high inefficiency rates and high production costs which have an impact on average selling prices, higher than in the rest of Europe.

The Law 144/1998, the so-called Bersani Reform, introduced a devolution process among regions. It abolished a set of regulations and the classification of retailing stores which had, in the past, not only obstructed the opening of new and large retailers, but also protected the existing network of smaller neighbourhood retailing shops. Previous legislation set both the maximum number of retailing stores per city district, calculated in terms of store surface area per inhabitant, and furthermore, the range of products and services a retailer was permitted to sell. Afterwards, the Bersani Reform was overcome by the Reform of the Title V of the Italian Constitution 
(Constitutional Law, 3/2001), which gave to the regions (i.e., administrative counties) the legislative power in this field and the opportunity to depart from the Bersani Reform. The rationalisation of the retail system has been carried out in a heterogeneous way among regions, predominantly in the food sector.

\section{Research Aim and Objectives}

The general aim of this study is to investigate the interaction between the evolution of new retailing format and general wealth and development in Italy, a country which has experienced, in the last years, a fairly good dynamic of the retail sector, particularly in its southern regions.

As outlined above, existing literature concerned with economic effects of retailing trade has focused on its impact on labour markets, price dynamics and inter-type competition, overlooking its influence on macro-economic factors. In particular, empirical analysis concerning the retail sector is focused on (Einarsson, 2008): (1) origin and evolution of the large retailing sector; (2) the causal link between socio-economic and productive factors; (3) the causes underlying the localisation of the large retailing formats in a given area, such as demand, per capita GDP, and employment rate; and (4) the main effects of large retailing, in its different forms, such as the relationship between producers and retailers, price dynamics and local employment levels. Other typologies of effects - the economic and social impact of modern retail on local economies — seems to be less explored or focused on specific aspects. This study tries to fill this gap by empirically investigating the association between key characteristics of large retailers and specific macro-economic factors—value added in specific sectors, such as agriculture, industry and services.

The research objective is to demonstrate the existence of an empirical association between the diffusion of modern retailing in the Italian food sector and some general economic indicators, i.e., total value added, value added in agriculture, industry, and service. The study of new retailing formats in the food sector is thus interpreted through the observation of two different typologies of selling points, i.e., super-markets and hyper-markets. This choice is based on the assumption that these two categories represent a good indicator of the dynamics of large retailing, and their presence has an impact on the development of the country, not only in terms of its price dynamics and occupation, but also as a stimulus of its economic activities and value added processes. This assumption is not new in the literature and has been implemented in some empirical studies carried out by ACNielsen, SVIMEZ and CESCOM-Bocconi. Supermarkets can be considered as a good indicator of the presence of the Large Scale Retail Trade within urban areas; hypermarkets-localized in urban areas or ex-urban areas within shopping centres (which represents the main appealing elements) -are the expression of the large organised retailing (Verhetsel, 2005).

\section{Methodology}

\section{Data Collection}

The present study has been conducted in Italy, by considering the longitudinal data that cover 19 years, from 1988 until to 2006, a period chosen as it overlaps with an innovative survey of the National Institute on Trade (Osservatorio Nazionale sul Commercio), which started, in 1988, a different method of measuring numerical consistency, areas and number of employees of modern retail, taking into account the two selling formats—super-markets and hyper-markets—separately. 
The dataset includes information on: (1) residents and some macroeconomic variables, from the Italian Institute of Statistics (Istituto Italiano di Statistica, ISTAT) and Krenos databanks—University of Cagliari (Italy); (2) super-markets and hyper-markets, taken from the National Institute on Trade (Osservatorio Nazionale sul Commercio) and the Italian Ministry of Industry and Trade (Ministero delle Attività Produttive). In particular, the dataset contains the subsequent time series observed in Italy over the period 1988-2006: (1) number of super-markets and hyper-markets; (2) selling areas of super-markets and hyper-markets; (3) national private consumption; (4) total value added and agriculture, industry and services value added according to the ATECO classification; and (5) value added for the ATECO categories, in particular, data on "Food, Beverages and Tobacco" for the industry sector, "Trade, Hotels and Public Establishment” and "Transport and Communication Services" for the service sector.

The consideration of the value added is functional for the appreciation of the country economic growth in terms of new goods and services. It corresponds, according to ISTAT, to the sum of the remuneration of productive factors and depreciations and can be calculated according to base prices or market prices (see the European Accounting System, SEC, 95). Value added is computed as the difference between the production value of goods and services and the value of intermediate goods and services employed for their manufacturing (input, auxiliary resources, and services supplied by other firms) (ISTAT, 2008). The variables describing the value added in the main sectors may represent good proxies of the wealth produced in those specific sectors, and the variables linked to the sub-sectors may represent proxies of the trend of economic activities in the sectors more directly exposed to the expansion of super-markets and hyper-markets: food, trade, and transports.

\section{Analysis and Results}

\section{Descriptive Statistics}

Before the description of the evolution, in Italy, of the considered new retailing formats-super-markets and hyper-markets - the trend of the economic indicators, represented by the value added in agriculture, industry, food and service sectors was analyzed. Results showed that, in Italy, the growth rate of the value added in the considered sectors was constant in the period from 1988 to 2006, even if it registered a higher growth of the service sector in comparison with the other ones (see Figure 1). Furthermore, the service sector represented the main contribution to the total value added — with a percentage near to the $70 \%$ - followed by the industrial sector — with a percentage between $30 \%$ and $25 \%$ — and by the agriculture sector—with a percentage lower than $7 \%$.

Descriptive analysis showed that the number of super-markets and hyper-markets increased significantly in the considered period from 1988 to 2006, the total number of supermarkets raised, in Italy, from 2,818 to 8,569, and the total number of hypermarkets increased from 40 to 490 (see Figure 2 and Figure 3).

Moreover, according to the National Institute on Trade (Osservatorio Nazionale sul Commercio), the average annual growth rate of the new retailing formats from 1991 to 2006 were significantly high — $6 \%$ for both super-markets and hyper-markets.

Data on the number and the retail area of super-markets and hyper-markets were considered in relation to population. In the period from 1988 to 2006, the number of super-markets and hyper-markets per 1,000 inhabitants in Italy augmented in a continuous and gradual way. In particular, the number of supermarkets per 1,000 inhabitants increased, in Italy, from 0.05 in 1988 to 0.15 in 2006, and the number of hypermarkets per 
1,000 inhabitants grew, from 0.001 in 1988 to 0.008 in 2006 (see Figure 4).

In the same period, the retail area of supermarkets per 1,000 inhabitants increased, in Italy, from 40 to 128 square meters, while the retail area of hypermarkets per 1,000 inhabitants increased from 4.4 to 51 (see Figure 5).

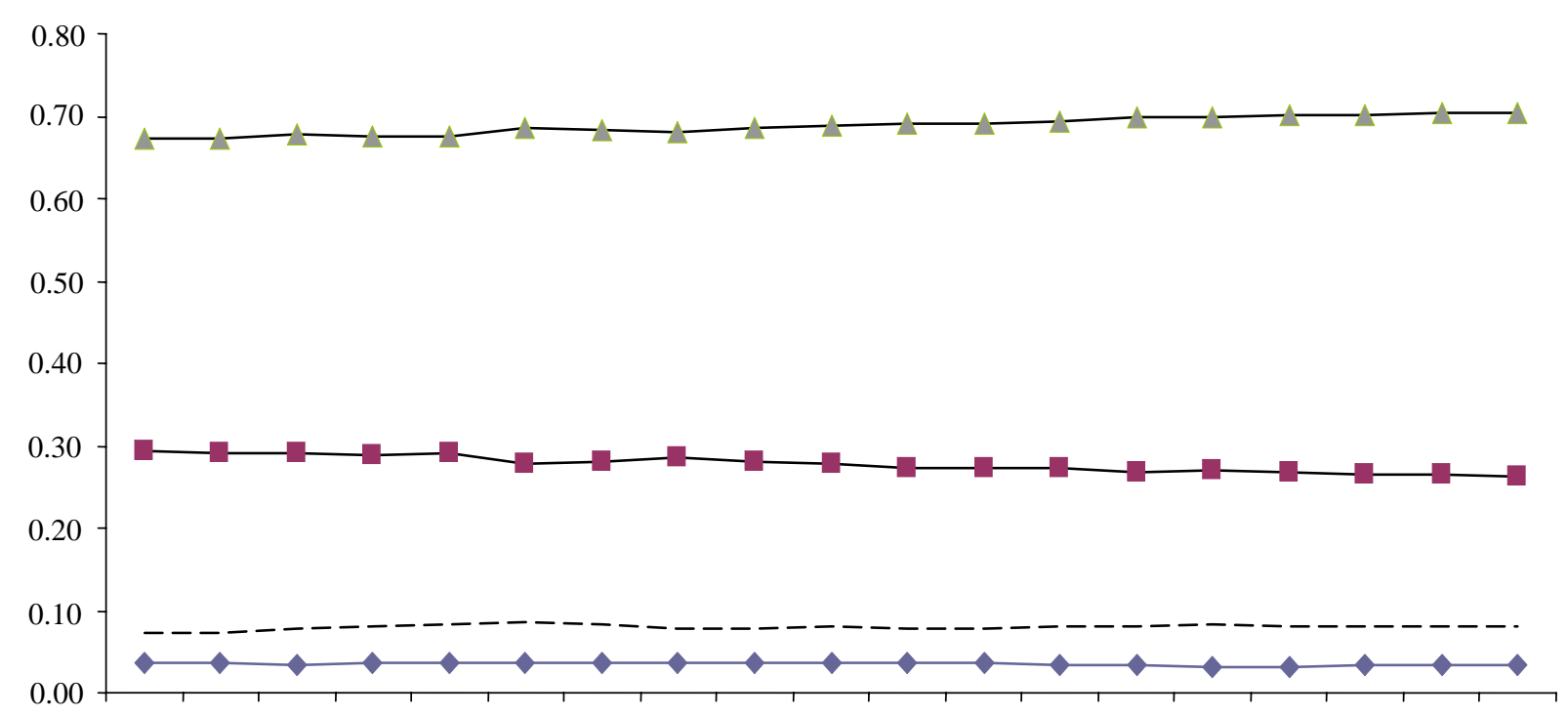

1988198919901991199219931994199519961997199819992000200120022003200420052006

$\checkmark$ Agriculture $-\square$-Industry $-\neg$ Services - - - .Food

Figure 1. Per-capita value added in agriculture, industry, food and service in Italy from 1988 to 2006. Source: Elaboration of data provided by Crenos and Istat.

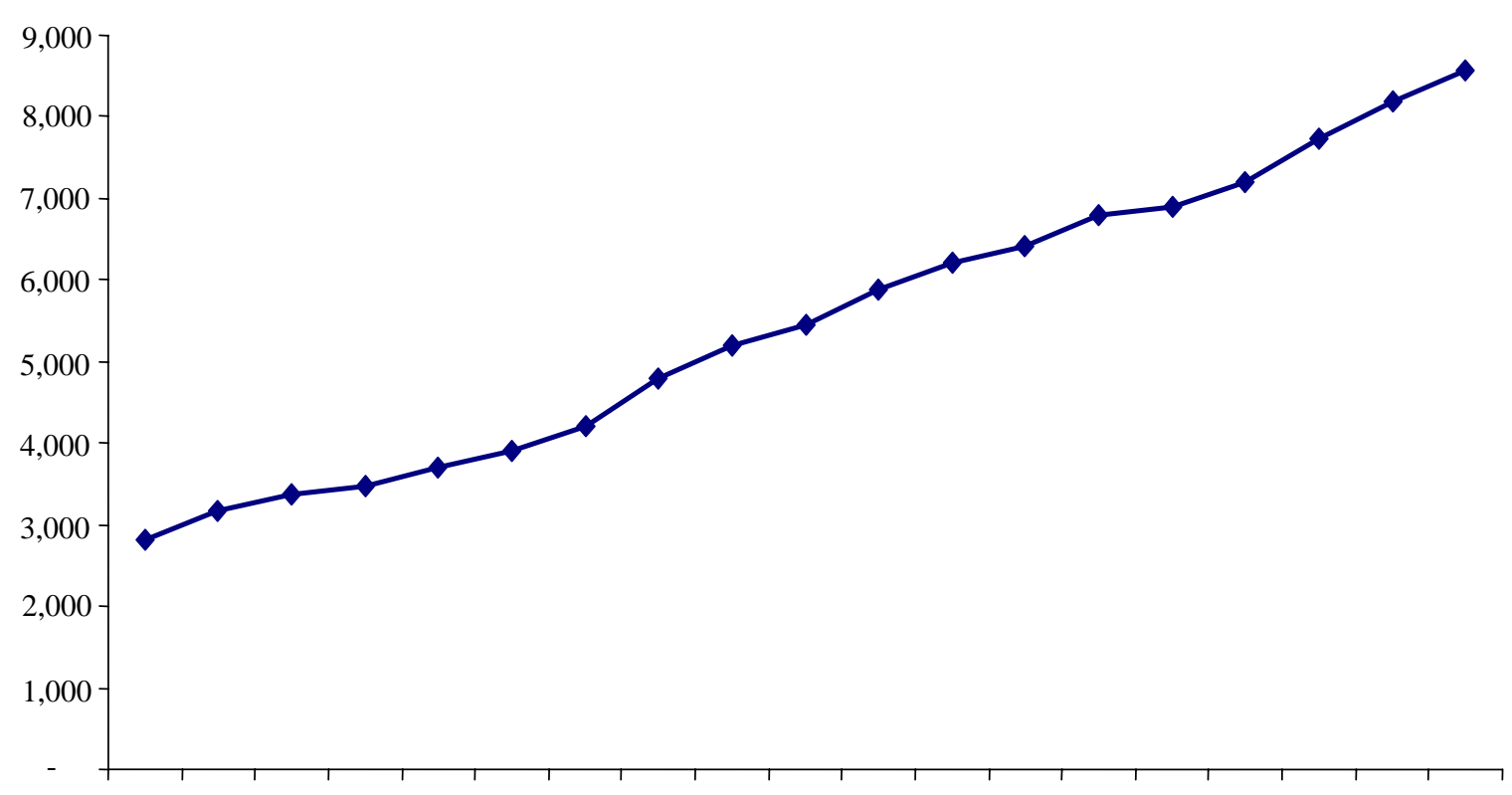

1988198919901991199219931994199519961997199819992000200120022003200420052006

Figure 2. Cumulative number of supermarkets in Italy from 1988 to 2006. Source: Elaboration of data provided by the National Institute on Trade (Osservatorio Nazionale sul Commercio). 


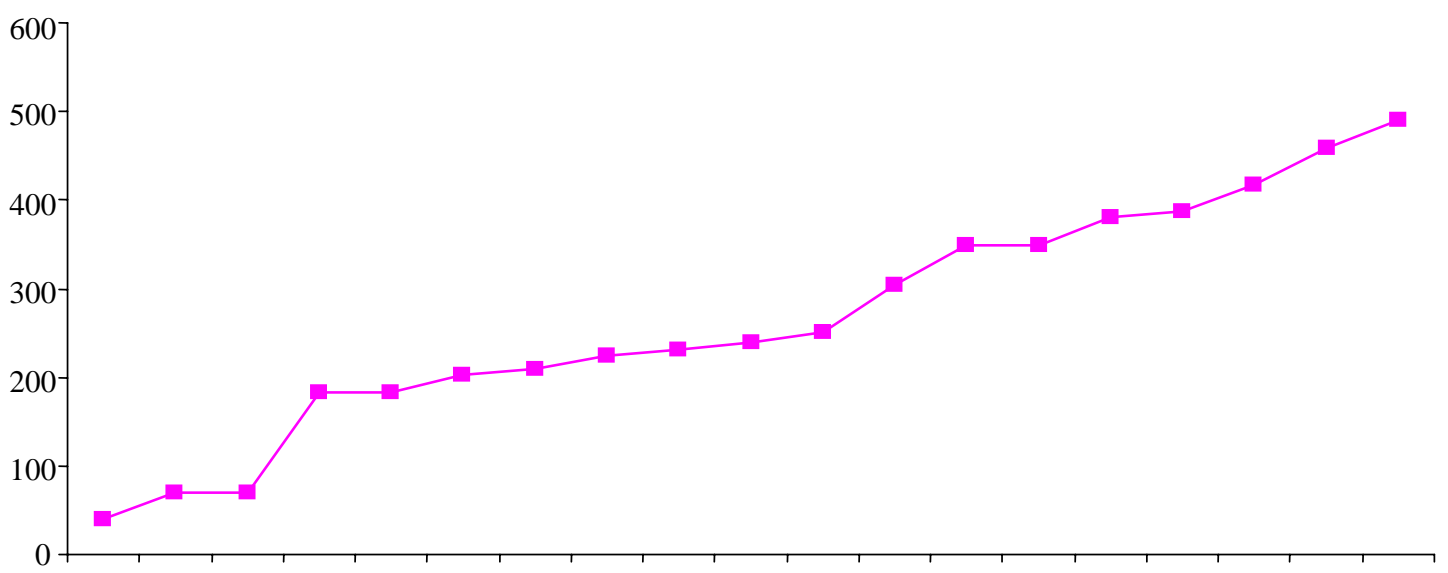

1988198919901991199219931994199519961997199819992000200120022003200420052006

Figure 3. Cumulative number of hypermarkets in Italy from 1988 to 2006. Source: Elaboration of data provided by the National Institute on Trade (Osservatorio Nazionale sul Commercio).

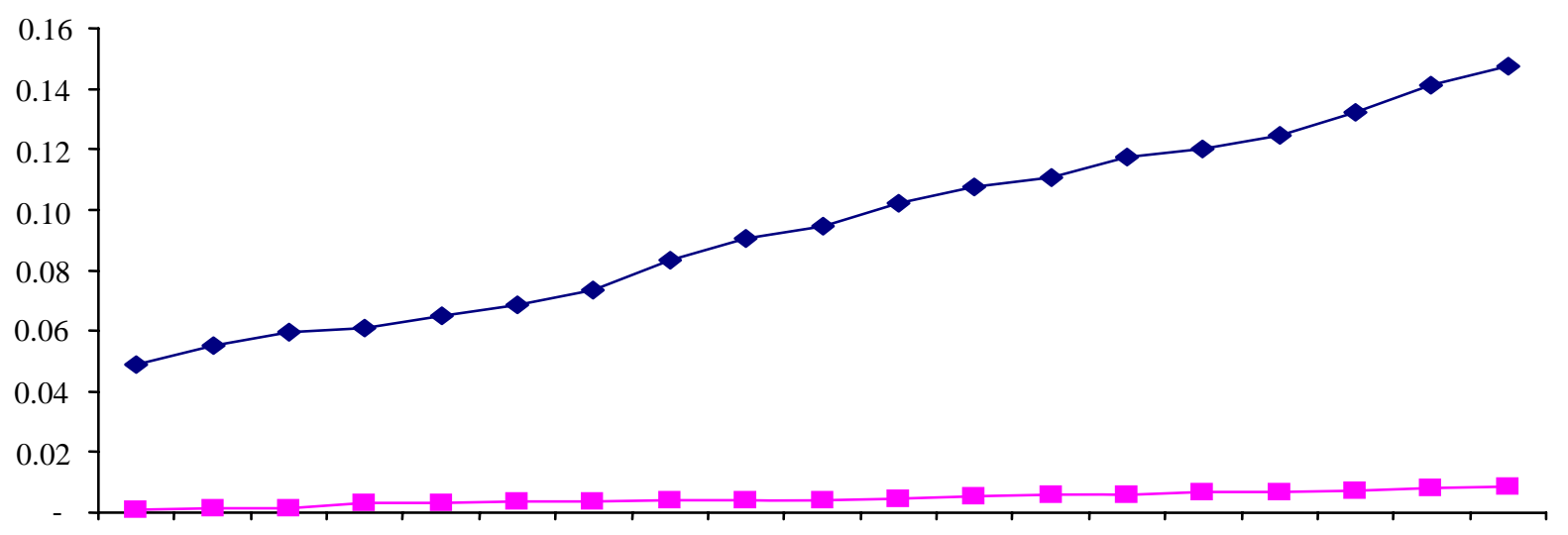

1988198919901991199219931994199519961997199819992000200120022003200420052006

\section{๑- Supermarkets - Hypermarkets}

Figure 4. Number of supermarkets and hypermarkets/1,000 inhabitants in Italy from 1988 to 2006. Source: Elaboration of data provided by the National Institute on Trade (Osservatorio Nazionale sul Commercio) and ISTAT.

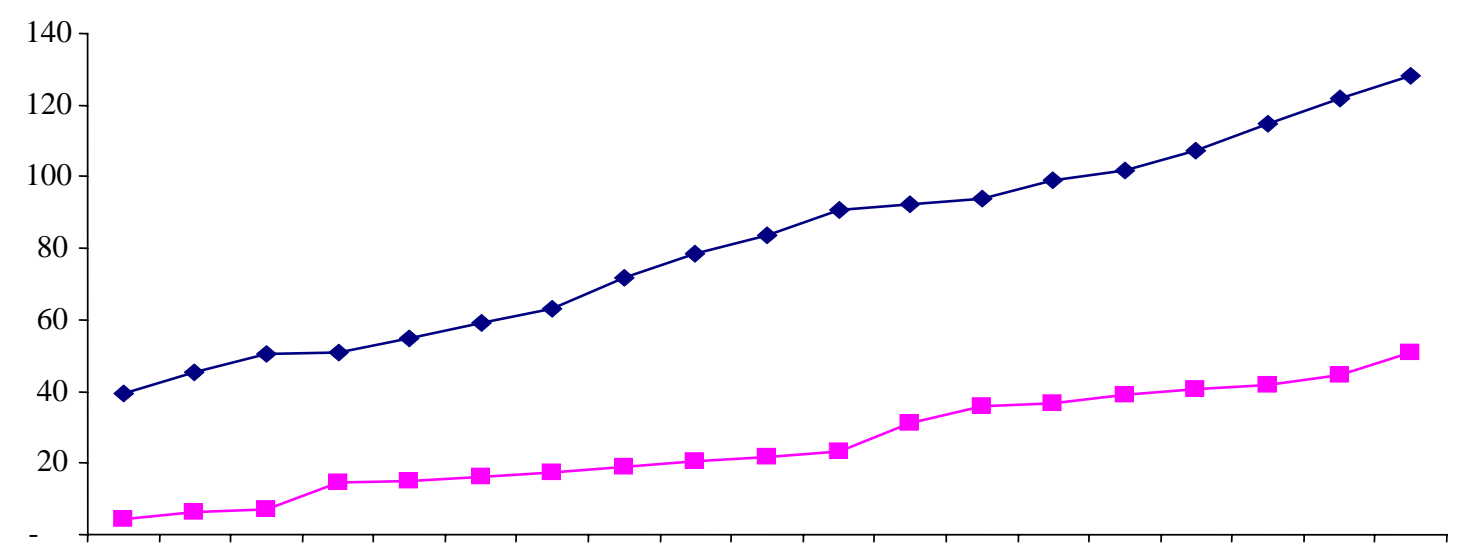

1988198919901991199219931994199519961997199819992000200120022003200420052006

$$
\rightarrow \text { Supermarkets } \rightarrow \text { - Hypermarkets }
$$

Figure 5. Retail area of supermarkets and hypermarkets/1,000 inhabitants in Italy from 1988 to 2006. Source: Elaboration of data provided by the National Institute on Trade (Osservatorio Nazionale sul Commercio) and ISTAT. 


\section{Linear Regression Analyses}

A series of regression analyses has been carried out by using the usual methodology OLS, in order to verify the existence of a linear relation between specific indicators of the diffusion of large retailing sector and economic indicators, such as the total value added. The dataset includes a balanced panel related to the 20 Italian administrative regions, observed in 19 annual temporal periods, from 1988 to 2006.

In order to obtain a unique variable for the large retailing sector, both for super-markets and hyper-markets, data related to the selling area, 1,000 inhabitants were considered. This indicator is deemed to be better than their numerical consistency to capture the pressure exerted by the large retailing sector in the local economic environment (Verhetsel, 2005). Furthermore, data related to super-markets and hyper-markets sales areas were considered, in order to obtain a unique indicator of the weight of the two forms of large retailing sector. Italian per capita consumption in the food sector was selected as a control variable. The following dependent variables were used in the linear regression analyses: (1) the value added in the agriculture sector; (2) the value added in the industry sector; (3) the value added in the service sector; and (4) the value added in the food sector. In order to observe the temporal effect, a temporal delay was considered: It has been assumed that the localisation of the large scale retail trade in a particular territory may explicate an impact on the economic territorial variables not only in the year of its establishment, but also some years later. To this end, linear regressions analyses took into consideration three different temporal periods: (1) delay $=0$ year; (2) delay $=2$ years; and (3) delay $=4$ years.

Results showed that, in Italy, the value added—related to the four specific sectors of agriculture, industry, services and food-has, usually, an influence on the principal explicative variable represented by retail area of super-markets and hyper-markets per 1,000 inhabitants. The presence and the intensity of this relation vary both on the basis of the particular sector and the temporal delay attributed to the dependent variable with respect to the explicative one ( $0,2,4$ years).

Table 1

Results of Linear Regression Analysis of Value Added in the Agriculture Sector, Null Delay, in Italy

\begin{tabular}{llllll}
\hline & $B$ & Std. error & Beta & $t$ & Sig. \\
\hline (Constant) & 0.049 & 0.002 & & 31.060 & 0.000 \\
Super/Hyper area & -0.000 & 0.000 & -0.390 & -8.240 & 0.000 \\
\hline
\end{tabular}

Notes. Dependent variable = value added in the agriculture sector; $N=380 ; R^{2}=0.196 ;$ Adjusted $R^{2}=0.192 ;$ Super/Hyper area $=$ Retail area of super-markets and hyper-markets per 1,000 inhabitants. Source: Elaboration of data provided by Crenos, Istat and the National Institute on Trade (Osservatorio Nazionale sul Commercio).

Table 2

Results of Linear Regression Analysis of Value Added in the Agriculture Sector, 2-Year Delay, in Italy

\begin{tabular}{llllll}
\hline & $B$ & Std. error & Beta & $t$ & Sig. \\
\hline (Constant) & 0.051 & 0.002 & & 30.510 & 0.000 \\
Super/Hyper area & -0.000 & 0.000 & -0.434 & -8.860 & 0.000 \\
\hline
\end{tabular}

Notes. Dependent variable = value added in the agriculture sector; $N=380 ; R^{2}=0.232$; Adjusted $R^{2}=0.227$; Super/Hyper area $=$ Retail area of super-markets and hyper-markets per 1,000 inhabitants. Source: Elaboration of data provided by Crenos, Istat and the National Institute on Trade (Osservatorio Nazionale sul Commercio). 
Table 3

Results of Linear Regression Analysis of Value Added in the Agriculture Sector, 4-Year Delay, in Italy

\begin{tabular}{llllll}
\hline & $B$ & Std. error & Beta & $t$ & Sig. \\
\hline (Constant) & 0.052 & 0.002 & & 29.500 & 0.000 \\
Super/Hyper area & -0.000 & 0.000 & -0.467 & -9.130 & 0.000 \\
\hline
\end{tabular}

Notes. Dependent variable = value added in the agriculture sector; $N=380 ; R^{2}=0.258$; Adjusted $R^{2}=0.253$; Super $/$ Hyper area $=$ Retail area of super-markets and hyper-markets per 1,000 inhabitants. Source: Elaboration of data provided by Crenos, Istat and the National Institute on Trade (Osservatorio Nazionale sul Commercio).

As regards the analysis related to the value added in agriculture, there is a relation with the establishment of large-scale retailing formats: In the situation of a null temporal delay, this index shows a negative relationship with a coefficient equal to $-0.390(p<0.000)$ and in the case of 2-year temporal delay it showed a coefficient equal to $-0.434(p=0.000)$. Moreover, this relation tended to be more significant in the situation of 4-year temporal delay (Beta $=-0.467 ; p=0.000$ ) (see Tables 1-3). Therefore, in the agriculture sector, the negative relationship with the large retailing formats seemed to be more significant with the passing of time.

Table 4

Results of Linear Regression Analysis of Value Added in the Industry Sector, Null Delay, in Italy

\begin{tabular}{lllrrl}
\hline & $B$ & Std. error & Beta & \multicolumn{1}{l}{ S } & Sig. \\
\hline (Constant) & 0.227 & 0.006 & & 35.730 & 0.000 \\
Super/Hyper area & 0.000 & 0.000 & 0.356 & 7.410 & 0.000 \\
\hline
\end{tabular}

Notes. Dependent variable = value added in the industry sector; $N=380 ; R^{2}=0.143$; Adjusted $R^{2}=0.138$; Super/Hyper area = Retail area of super-markets and hyper-markets per 1,000 inhabitants. Source: Elaboration of data provided by Crenos, Istat and the National Institute on Trade (Osservatorio Nazionale sul Commercio).

Table 5

Results of Linear Regression Analysis of Value Added in the Industry Sector, 2-Year Delay, in Italy

\begin{tabular}{llllrl}
\hline & $B$ & Std. error & Beta & $t$ & Sig. \\
\hline (Constant) & 0.219 & 0.007 & & 32.710 & 0.000 \\
Super/Hyper area & 0.000 & 0.000 & 0.395 & 7.900 & 0.000 \\
\hline
\end{tabular}

Notes. Dependent variable = value added in the industry sector; $N=380 ; R^{2}=0.176$; Adjusted $R^{2}=0.172$; Super/Hyper area = Retail area of super-markets and hyper-markets per 1,000 inhabitants. Source: Elaboration of data provided by Crenos, Istat and the National Institute on Trade (Osservatorio Nazionale sul Commercio).

Table 6

Results of Linear Regression Analysis of Value Added in the Industry Sector, 4-Year Delay, in Italy

\begin{tabular}{llllrl}
\hline & $B$ & Std. error & Beta & $t$ & Sig. \\
\hline (Constant) & 0.213 & 0.007 & & 29.660 & 0.000 \\
Super/Hyper area & 0.001 & 0.000 & 0.424 & 8.090 & 0.000
\end{tabular}

Notes. Dependent variable = value added in the industry sector; $N=380 ; R^{2}=0.210$; Adjusted $R^{2}=0.205$; Super/Hyper area = Retail area of super-markets and hyper-markets per 1,000 inhabitants. Source: Elaboration of data provided by Crenos, Istat and the National Institute on Trade (Osservatorio Nazionale sul Commercio).

Results related to the industrial sector registered a positive relationship, in each temporal delays observed $(p=0.000)$. The linear regression analysis showed an increase of value added in the industrial sector in 
correspondence to the expansion of super-markets and hyper-markets in Italy, and this effect tends to be more important after some years of their settlement. Indeed, in the situation of the null delay the coefficient is equal to 0.356; in the case of 2-year delay the coefficient corresponds to 0.395 , while in the situation of 4-year delay, the coefficient is equal to 0.424 (see Tables 4-6).

In the food sector, ATECO, beverages and tobacco, a sub-sector of industry, the relation with the evolution of super-markets and hyper-markets showed divergent results, if compared with the entire industrial sector. In the situation of the null delay the coefficient is equal to $-0.291(p=0.000)$, and in the case of 2-year delay, the coefficient is equal to $-0.352(p=0.000)$, and in the situation of the 4-years delay, the coefficient is equal to $-0.410(p=0.000)$ (see Tables 7-9).

Table 7

Results of Linear Regression Analysis of Value Added in the Food Sector, Null Delay, in Italy

\begin{tabular}{llllll}
\hline & $B$ & Std. error & Beta & $t$ & Sig. \\
\hline (Constant) & 0.097 & 0.003 & & 37.760 & 0.000 \\
Super/Hyper area & -0.000 & 0.000 & -0.291 & -5.910 & 0.000 \\
\hline
\end{tabular}

Notes. Dependent variable $=$ value added in the food sector; $N=380 ; R^{2}=0.084$; Adjusted $R^{2}=0.080$; Super/Hyper area = Retail area of super-markets and hyper-markets per 1,000 inhabitants. Source: Elaboration of data provided by Crenos, Istat and the National Institute on Trade (Osservatorio Nazionale sul Commercio).

Table 8

Results of Linear Regression Analysis of Value Added in the Food Sector, 2-Year Delay, in Italy

\begin{tabular}{llllll}
\hline & B & Std. error & Beta & $t$ & Sig. \\
\hline (Constant) & 0.101 & 0.003 & & 37.070 & 0.000 \\
Super/Hyper area & -0.000 & 0.000 & -0.352 & -6.920 & 0.000 \\
\hline
\end{tabular}

Notes. Dependent variable = value added in the food sector; $N=380 ; R^{2}=0.125$; Adjusted $R^{2}=0.119$; Super/Hyper area = Retail area of super-markets and hyper-markets per 1,000 inhabitants. Source: Elaboration of data provided by Crenos, Istat and the National Institute on Trade (Osservatorio Nazionale sul Commercio).

Table 9

Results of Linear Regression Analysis of Value Added in the Food Sector, 4-Year Delay, in Italy

\begin{tabular}{llllll}
\hline & $B$ & Std. error & Beta & $t$ & Sig. \\
\hline (Constant) & 0.105 & 0.003 & & 36.020 & 0.000 \\
Super/Hyper area & -0.000 & 0.000 & -0.410 & -7.760 & 0.000 \\
\hline
\end{tabular}

Notes. Dependent variable = value added in the food sector; $N=380 ; R^{2}=0.169$; Adjusted $R^{2}=0.163$; Super/Hyper area = Retail area of super-markets and hyper-markets per 1,000 inhabitants. Source: Elaboration of data provided by Crenos, Istat and the National Institute on Trade (Osservatorio Nazionale sul Commercio).

This outcome seems to be in contrast with previous considerations regarding the industrial sector, as in the food sub-sector the expansion of super-markets and hyper-markets in the Italian territory affects a decrease of the value added in the food sector. Also the other observed industrial sector, the service one, showed a negative relationship between the evolution of large retailing formats and the related macroeconomic variables, in each of the different observed delay. Specifically, unlike the industry sector, in general, results exhibited a negative relationship in the situation of the null delay, with a coefficient equal to -0.261 $(p<0.000)$; in the case of 2-year delay, it obtained a coefficient equal to $-0.292(p<0.000)$; while in the situation of 4-year delay, it showed a coefficient 
equal to -0.319 $(p<0.000)$ (see Tables 10-12). As for the food sub-sector, the new settlement of super-markets and hyper-markets in the Italian territory would negatively impact the value added in the service sector.

Table 10

Results of Linear Regression Analysis of Value Added in the Service Sector, Null Delay, in Italy

\begin{tabular}{llllrl}
\hline & $B$ & Std. error & Beta & \multicolumn{1}{l}{ S } & \multicolumn{1}{l}{ Sig. } \\
\hline (Constant) & 0.723 & 0.006 & & 115.000 & 0.000 \\
Super/Hyper area & -0.000 & 0.000 & -0.261 & -5.250 & 0.000 \\
\hline
\end{tabular}

Notes. Dependent variable = value added in the service sector; $N=380 ; R^{2}=0.101$; Adjusted $R^{2}=0.096$; Super/Hyper area = Retail area of super-markets and hyper-markets per 1,000 inhabitants. Source: Elaboration of data provided by Crenos, Istat and the National Institute on Trade (Osservatorio Nazionale sul Commercio).

Table 11

Results of Linear Regression Analysis of Value Added in the Service Sector, 2-Year Delay, in Italy

\begin{tabular}{llllrl}
\hline & $B$ & Std. error & Beta & $t$ & Sig. \\
\hline (Constant) & 0.729 & 0.007 & & 108.790 & 0.000 \\
Super/Hyper area & -0.000 & 0.000 & -0.292 & -5.610 & 0.000 \\
\hline
\end{tabular}

Notes. Dependent variable = value added in the service sector; $N=380 ; R^{2}=0.127$; Adjusted $R^{2}=0.122$; Super/Hyper area = Retail area of super-markets and hyper-markets per 1,000 inhabitants. Source: Elaboration of data provided by Crenos, Istat and the National Institute on Trade (Osservatorio Nazionale sul Commercio).

Table 12

Results of Linear Regression Analysis of Value Added in the Service Sector, 4-Year Delay, in Italy

\begin{tabular}{llllll}
\hline & $B$ & Std. error & Beta & \multicolumn{1}{l}{ Sig. } \\
\hline (Constant) & 0.734 & 0.007 & & 102.230 & 0.000 \\
Super/Hyper area & -0.000 & 0.000 & -0.319 & -5.800 & 0.000 \\
\hline
\end{tabular}

Notes. Dependent variable = value added in the service sector; $N=380 ; R^{2}=0.159 ;$ Adjusted $R^{2}=0.153$; Super/Hyper Area = Retail area of super-markets and hyper-markets per 1,000 inhabitants. Source: Elaboration of data provided by Crenos, Istat and the National Institute on Trade (Osservatorio Nazionale sul Commercio).

\section{Discussion}

Results obtained showed the presence of a general relationship between both variables related to total value added and value added in specific sectors and a syntethic index related to the evolution of large retailing formats in Italy. This relationship, which is positive or negative on the basis of different observed sectors, seems to increase - either positively, or negatively_according to the temporal delay considered between the settlement of new super-markets and hyper-markets and the measurement of value added.

In the agriculture sector, the presence of a negative relationship with the diffusion of super-markets and hyper-markets was significant in the initial stage of their introduction and tended to deteriorate its effect in the following years. In the industrial sector, the creation and enlargement of retail area of new retailing formats had a positive impact on the value added provided by the national industry, in general. These effects were intensified as the temporal delay of measurement increased, therefore super-markets and hyper-markets positively influenced manufacturing and commercial companies after some years of their establishment. The positive effect on the industrial segment does not appear to be homogeneous for each sub-sectors. In particular, the food sub-sector 
(namely, ATECO-ISTAT Food, Beverages and Tobacco) — one of the traditional sectors of made in Italy —seems to be damaged from the proliferation of large sales formats in the territory. Both in the situation of null delay and in the case of 2-year and 4-year delay, the effects deriving from the creation and evolution of super-markets and hyper-markets, appear to be negative and also increasingly depressing in the long run. A negative relationship was also registered for the service sector, which showed an inverse association between index of large retailing sector and value added, in the three considered measurement periods. Therefore, the establishment of large-scale retailing formats would cause unfavorable effects both on the food and the service industries.

These results confirm some detrimental influences of the proliferation of modern forms of retailing previously evidenced in certain empirical studies in the literature, which emphasize the negative effects of large retailing formats on the growth and development of main economic sectors, for example, studies on the impact of Wal-Mart (Drewianka \& Dain, 2004; Dube , Eidlin, \& Lester, 2005), and reports of the Competition Commission in the United Kingdom (2000), and of the FXM associates in the Cape Code Region (2005).

Our research confirms that the favourable impact of large retailing sector spreads in a heterogeneous manner in economic sectors (Mileti \& Prete, 2009). It also confirms the long-standing problems stressed by small food companies and farms regarding the economic harms caused by the so called "long retailing channel” adopted by large retailers, intended as the logistic supplying chain with the suppliers of food products localised kilometres away from the selling points. In that respect, market globalisation—extended to food products-allows super-markets and hyper-markets to select food products among a wide set of possibilities and, furthermore, it pushes a cost-driven competition among suppliers which leads to lower returns. The power exerted by modern trade in the channel retail—as documented in the literature (Ailawadi, 2001; Buzzell, Quelch \& Salmon, 1990)—might discourage those public policies intended to promote the development of food sectors and based on investment-oriented subsidies and grants.

\section{Limitation and Future Research}

The present study has some limitations, particularly deriving from the difficulty of collecting data, as in retailing studies, the need of updated data is only partially fulfilled by the official statistical sources. Files and data made available by different Institutions (Ministero delle Attività Produttive, Infocamere, Istat) are often incomplete, dissonant and referred to different criteria when surveying heterogeneous selling points (Gismondi \& Giorgi, 2002). The analysis conducted on supermarkets and hypermarkets data has also highlighted some problems. Even though the classification criterion based on the selling area is the most frequently used (Osservatorio Nazionale sul Commercio, AC-Nielsen, IRI-Infoscan), it is not an official criterion used by ISTAT (Marbach et al., 2000), and furthermore, the simple data relative to the numerical consistency of retailers diverges according to different sources and empirical studies. The most reliable source, the Osservatorio Nazionale sul Commercio, provides discontinuous data, for example, the data collection on the numerical consistency of retailers has been interrupted in 1996 and started again in 2000. Moreover, the first data on hypermarkets — collected by the Osservatorio—are available from 1988, while for the previous years they are included in the data for supermarkets.

Future research should try to broaden the analysis presented in this paper, by considering further territorial areas and food retailing channels. The present study is based on the assumption that only supermarkets and 
hyper-markets characterise and affect the targeted local economies and their production structure. As a matter of fact, investments and regional value added might depend, among other variables, on large resellers located in wider areas, i.e., macro-regions, national and international areas, or on very new retailing formats, i.e., e-commerce. In the modern market, characterised by the globalisation of trade and economies, many producers are not only active in local markets, but they can distribute their products outside regional and national borders. Furthermore, e-commerce-the purchasing, selling, and exchanging of goods and services on the internet, especially on the World Wide Web and its main categories, such as B2B (business-to-business) - companies doing business with each other; B2C (business-to-consumer)—companies selling to the general public; C2B (consumer-to-business)—individuals offering goods and services to companies; and C2C (consumer-to-consumer) — transactions between consumers on the websites offering auctions and forums, could have an impact on value added and on investments.

Finally, future research could extend the analysis presented in this paper by taking into account and deepen the nature of the link among large retailing, investments and value added variables, and the coexistence of other explanatory factors, such as infrastructures, morphological and local social structures (IRES, 2002).

\section{Conclusion}

This study shows that the diffusion of super-markets and hyper-markets differently interacts with some important local development variables, i.e., total value added and value added in specific sectors, observed over a 19-year-period in Italy. Local administrations should encourage networking activities, such as consortia among farms for the development of region-of-origin brands, and agreements among producers and retailers in order to assure a price system that could re-allocate profits among parties in a more homogenous way.

\section{References}

Ailawadi, K. (2001). The retail power-performance conundrum: What have we learned? Journal of Retailing, 77(3), 299-318.

Baron, S., Harris, K., Leaver, D., \& Oldfield, B. M. (2001). Beyond convenience: The future for independent food and grocery retailers in the UK. International Review of Retail, Distribution and Consumer Research, 11(4), 395-414.

Basker, E. (2005). Job creation or destruction? Labor market effects of Wal-Mart expansion. Review of Economics and Statistics, 87, 174-183.

Beresteanu, A., \& Ellickson, P. (2006). The dynamics of retail oligopoly. Retrieved May 15, 2008, from www.aeaweb.org/annual_mtg_papers/2007(0107_1015_1204.pdf

Bertozzi, P. (2006). L’Impatto territoriale del grande commercio. Impresa e Stato, 42. Retrieved May 15, 2008, from www.impresa-stato.mo.camcom.it/i_42/bertozzi.htm

Buzzell, R., Quelch, J., \& Salmon, W. (1990). The costly bargain of trade promotion. Harvard Business Review, 68, 141-149.

Clarke, R. (2001). Buyer power and competition in food retailing in the UK. Briefing Notes in Economics, Commemorative Issue, 50, September/October.

Cliquet, G. (2000). Large format retailers: A French tradition despite reactions. Journal of Retailing and Consumer Services, 7 , 183-195.

Coca-Stefaniak, A., Hallsworth, A. G., Parker, C., Bainbridge, S., \& Yuste, R. (2005). Decline in the British small shop independent retail sector: Exploring European parallels. Journal of Retailing and Consumer Services, 12, 357-371.

Drewianka, S., \& Johnson, D. (2004). Wal-Mart and local labor markets, 1990-2004. Retrieved May 15, 2008, from www.newrules.org/retail/neumarkstudy.pdf

Dube, A., Eidlin, B., \& Lester. B. (2005). Impact of Wal-Mart growth on earnings throughout the retail sector in urban and rural counties. Working paper, Institute of Industrial Relations. Berkeley: University of California.

Dunne, P. M., \& Lusch, R. F. (1999). Retailing. New York: Dryden Press. 
Einarsson, A. (2008). The retail sector in the Nordic countries: A description of the differences, similarities, and uniqueness in the global market. Journal of Retailing and Consumer Services, 15, 443-451.

Farhangmehr, M., Marques, S., \& Silva, J. (2001). Hypermarkets versus traditional retail stores—Consumers and retailers' perspectives in Braga: A case study. Journal of Retailing and Consumer Services, 8, 189-198.

Gismondi, A. R., \& Giorgi, R. (2002). Retail trade turnover by kind of product in 1997. Contributions, 48. Rome: ISTAT.

Gordon, D., \& Walton, J. (2000). Convenience retailing 2000: The market review. Letchmore Heath: IGD Business Publication.

Guariglia, A. (2002). Superstore and labour demand: Evidence from Great Britain. Journal of Applied Economics, 5(2), $233-252$.

Guido, G. (2007). The development of tourist and industrial districts in south Italy: A strategic marketing perspective. Sinergie, 26, 191-200.

IRES. (2002). Piccolo, Grande, Nuovo. Il Commercio in Piemonte Prima della Riforma. Turin: Osservatorio Regionale sul Commercio.

Lago, U. (2002). Grande distribuzione e piccola e media industria. Milan: Egea.

Marbach, G., Barile, M., Carlucci, M., \& de Martino, V. (2000). Verso la Trasparenza dei Dati sulla Distribuzione Commerciale ed i Consumi delle Famiglie Italiane. Commissione per la Garanzia dell’Informazione Statistica, Rappor to No. 00.06. Retrieved May 15, 2008, from www.palazzochigi.it/Presidenza/statistica/attivita/rapporti/2000/00.06.pdf

Mileti, A., \& Prete, M. I. (2009). How super-markets and hyper-markets contribute to the Italian local development. Paper presented to the 6th International Conference for Consumer Behavior and Retailing Research. Vorarlberg, University of Applied Sciences, Austria.

Neumann, T. (2006). Retail chains, store size, \& the specialization of retail labor: 1910-1970. Evidence from Population Census Data. Retrieved May 15, 2008, from www.faculty.ucmerced.edu/tneumann/economics/research_files/cv.pdf

Pellegrini, L. (2001). Il Commercio in Italia. Bologna: Il Mulino.

Peston, L., \& Ennew, C. T. (1998). Neighbourhood shopping in the millennium. University of Nottingham Business School Discussion Paper, XII, October.

Prasad, J., \& Reddy, D. (2007). A study on the role of demographic and psychographic dynamics in food and grocery retailing. The Journal of Business Perspective, 4(1), 23-34.

Stock, J. H., \& Watson, M. W. (2006). Introduction to econometrics (2nd ed.). Addison-Wesley Series in Economics.

Verhetsel, A. (2005). Effects of neighborhood characteristics on store performance supermarkets versus hypermarkets. Journal of Retailing and Consumer Services, 12, 141-150. 